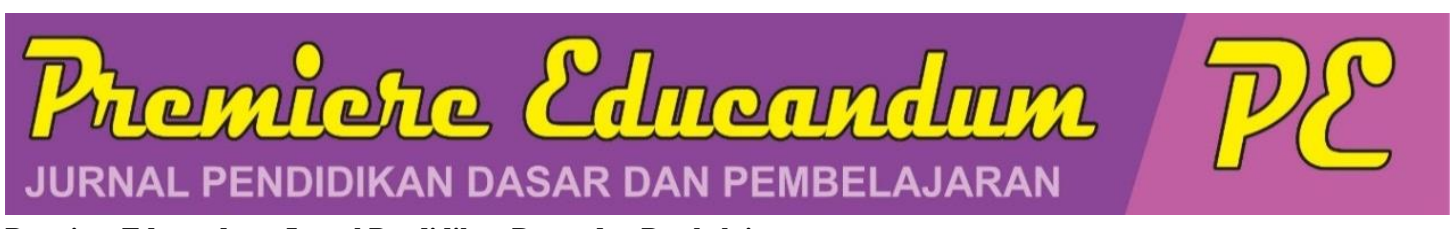

Premiere Educandum: Jurnal Pendidikan Dasar dan Pembelajaran

Volume 9 (2) 100 - 111 Desember 2019

Copyright @2019 Universitas PGRI Madiun

ISSN: 2088-5350 (Print) / ISSN: 2528-5173 (Online)

Available at: http://e-journal.unipma.ac.id/index.php/PE

Doi: $10.25273 /$ pe.v9i2.4501

\title{
Peran orang tua dan guru dalam mengembangkan nilai-nilai karakter anak usia sekolah dasar
}

\author{
Ahmad Yasar Ramdan'), Puji Yanti Fauziah'2) \\ 1,2Pendidikan Luar Sekolah, Universitas Negeri Yogyakarta \\ 1email: ahmadyasar.2018@student.uny.ac.id \\ 2email: pujiyanti@uny.ac.id
}

\begin{abstract}
This study aims to (1) analyze the role of parents and teachers in developing children's character; (2) factors that influence children's character development; (3) the impact of the role of parents and teachers on the development of the character of children in SD Muhammadiyah Sapen. This study uses descriptive qualitative research. Data sources were obtained from the principal, class teacher, religious education teacher, committee chairman, and parents. Data collection is done through interviews, observation and documentation. Data was then analyzed by interactive models that followed the format of Miles \& Huberman, including: data reduction, data presentation and conclusions. The results showed that the role of parents and teachers as role models for children in attitude and personality, such as honesty, tolerance, discipline, responsibility, religion, and caring for others and the environment. Supporting factors are curriculum content standards, principal leadership, school community commitment, and involve the role of parents in school programs. While the inhibiting factor is the apathy of some parents and teachers, and the lack of parental knowledge about character education. The impact of the role of parents and teachers is: (1) Character values affect children's learning achievement, (2) The occurrence of behavioral changes that occur in children.
\end{abstract}

Keywords: the role of parents and teachers, role model, achievement and children's character

\section{Abstrak}

Penelitian ini bertujuan untuk (1) menganalisis peran orangtua dan guru dalam mengembangkan karakter anak; (2) faktor-faktor yang mempengaruhi pengembangan karakter anak; (3) dampak peran orangtua dan guru terhadap pengembangan karakter anak di SD Muhammadiyah Sapen. Penelitian ini menggunakan penelitian deskriptif kualitatif. Sumber data diperoleh dari kepala sekolah, guru kelas, guru pendidikan Agama, ketua komite, dan orangtua. Pengumpulan data dilakukan melalui wawancara, observasi dan dokumentasi. Data kemudian dianalisis dengan model interaktif yang mengikuti format dari Miles \& Huberman, meliputi: reduksi data, penyajian data dan kesimpulan. Hasil penelitian menunjukkan bahwa peran orangtua dan guru sebagai role model bagi anak dalam bersikap dan berkepribadian, seperti sikap jujur, toleransi, disiplin, bertanggung jawab, religius, dan peduli terhadap orang lain serta lingkungan. Faktor pendukung yaitu standar isi kurikulum, kepemimpinan kepala sekolah, komitmen warga sekolah, dan melibatkan peran orangtua dalam program sekolah. Sedangkan faktor penghambat adalah sikap apatis dari beberapa orangtua dan guru, dan minimnya pengetahuan orangtua tentang pendidikan karakter. Dampak peran orang tua dan guru yaitu: (1) Nilai-nilai karakter berpengaruh terhadap prestasi belajar anak, (2) Terjadinya perubahan perilaku yang muncul pada anak.

Kata Kunci: peran orangtua dan guru, role model, prestasi dan karakter anak

Histori artikel : disubmit pada 23 Juni 2019; direvisi pada 26 September 2019; diterima pada 26 September 2019 


\section{A. PENDAHULUAN}

Pendidikan diharapkan dapat mengambil bagian penting dalam mencerdaskan dan menanamkan nilainilai karakter yang baik pada anak. Pendidikan karakter dalam konteks pendidikan di Indonesia adalah pendidikan nilai-nilai luhur yang berdasarkan budaya bangsa Indonesia sendiri untuk mengupayakan membentuk dan membina anak menjadi generasi penerus bangsa (Uli, 2018). Dalam rangka mencapai tujuan yang luhur itu, maka diperlukan kerjasama dan kolaborasi semua pihak dalam mendidik serta membimbing anak ke arah yang lebih baik. Karena pendidikan adalah tanggungjawab bersama antara sekolah, orangtua, dan masyarakat sebagai tri pusat pendidikan. Orang tua menjadi referensi pertama dan pendidik utama bagi anak, baik dari dalam kandungan hingga anak menyelesaikan studinya. Peran orangtua sangat penting dalam mendidik anak, walaupun mereka tidak mendapatkan pendidikan dan pelatihan bagaimana menjadi orang tua ideal sebagaimana dalam menyiapkan guru atau tenaga kependidikan. Tidak ada sekolah formal yang khusus melatih dan mengajarkan menjadi orang tua ideal, tapi mereka belajar dari pengalaman pola asuh orangtua mereka dahulu (Iv et al., 2017).

Dalam mengembangkan karakter anak, peran guru juga memiliki peran penting sebagai figur utama di sekolah dalam membimbing dan mendidik anak. Guru sebagai orangtua anak di sekolah. Untuk itu keberhasilan prestasi belajar anak tergantung dari tingkat kemampuan guru dalam membuat iklim proses belajar mengajar yang nyaman. Wawasan, kedisiplinan, motivasi, iklim belajar yang nyaman dan kondusif, kesejahteraan, serta budaya sekolah merupakan aspek keberhasilan guru dalam kegiatan belajar mengajar (Agustina, 2018). Maka dari itu, peran guru sebagai pendorong dalam meningkatkan mutu pendidikan serta membentuk kepribadian anak menjadi lebih baik.

Namun, kenyataannya pendidikan dewasa ini hanya lebih memperhatikan aspek intelektual daripada memperhatikan aspek emosional dan spiritual, maka tidak heran jika banyak kita melihat perilaku menyimpang dari anak (Hardiyana, 2014). Meningkatnya perilaku menyimpang ini menyebabkan menurunnya prestasi belajar anak, karena anak yang memiliki perilaku yang baik berpengaruh terhadap prestasi belajarnya. Penelitian yang dilaksanakan di SDIT Salman AlFarisi menunjukkan bahwa diantara nilai-nilai karakter anak, karakter disiplin memiliki pengaruh yang positif dan signifikan terhadap prestasi belajar anak (Irjanti \& Setiawati, 2018)

Peran guru dan orangtua telah menjadi isu terhangat yang banyak dipermasalahkan dalam dunia pendidikan. Masalahnya, sering terjadi perdebatan siapa pihak yang bertanggung jawab ketika anak mengalami penurunan prestasi belajar atau perilaku anak kurang mencerminkan sikap yang baik. Orangtua sering memiliki anggapan bahwa sesungguhnya guru dan lingkungan sangat berperan penting terhadap pendidikan anak (Sugihandari, 2015). Sehingga orang tua selalu menyalahkan guru dengan sistem pembelajaran yang diterapkan di sekolah, dan begitu juga dengan guru menyalahkan pola pengasuhan orangtua terhadap anak di rumah.

Peran guru yang baik kinerja dan memiliki kepribadian yang baik menjadi sorotan masyarakat sebagai figur teladan bagi anaknya dalam 
mendidik dan mengarahkan kepribadian anak menjadi lebih baik. (Palunga \& Marzuki, 2017). Dalam membentuk kepribadian anak bukan hanya menjadi tanggungjawab guru di sekolah, namun menjadi tanggungjawab orang tua untuk terlibat secara aktif membiasakan dan mengarahkan dalam pembentukan karakter anak di rumah. Likona, Schapss \& Lewis menjelaskan bahwa kemitraan antara orangtua dan sekolah menjadi bagian terpenting dalam mengembangkan karakter anak (Lies, Bronk, Mariano, 2008). Membangun komunikasi yang baik antara sekolah dan orangtua menjadi faktor terpenting bagi pengembangan karakter anak, sehingga menyelaraskan iklim yang dibangun antara pendidikan di sekolah dan di rumah. Ada beberapa faktor yang dapat mempengaruhi pengembangan karakter anak, salah satu faktor yang memiliki peran utama dan pengaruh dalam pembentukan sosial anak adalah peran dari keluarga (Cecillia, Jumaini \& Ganis, 2014).

Berdasarkan hasil penelitian telah menjabarkan secara jelas bahwa peran orangtua dan guru memberikan kontribusi positif terhadap perkembangan anak. Keadaan keluarga turut memberikan pengaruh terhadap prestasi belajar anak di sekolah. Dengan lingkungan memberikan anak merasa dicintai, didukung, dihargai, tingkat perhatian orangtua terhadap perilaku anak, dan toleransi untuk mendorong perkembangan kemandirian anak (Steinberg, 1996). Dalam penelitian lain telah dijelaskan bahwa guru berperan sebagai teladan bagi anak untuk memberikan contoh yang baik dalam berperilaku seperti: sopan santun, disiplin, jujur, toleransi, tanggung jawab, serta bersikap peduli kepada orang lain (Palunga \& Marzuki, 2017).
Tujuan pendidikan adalah usaha untuk mengembangan kepribadian anak secara menyeluruh ke arah yang positif, konstruktif, dan berakhlak mulia, termasuk dalam mempertahankan karakter baik dalam diri anak (Zaini, 2013). Sebagai orang yang digugu dan ditiru, orang tua dan guru berperan sangat penting dalam menanamkan nilai-nilai moral, etika, estetika, budi pekerti yang baik, dan mengimplementasikan pendidikan berdasarkan pengembangan karakter, sehingga dapat diaplikasikan oleh anak dalam kehidupan sehari-sehari.

Sebagai orang yang menjadi role model (panutan) bagi anak, maka orangtua dan guru sepatutnya memberikan contoh dalam berperilaku atau bersikap yang baik. Dengan harapan, bahwa apa yang menjadi pembiasaan anak di lingkungan sekolah dan rumah terintegrasi dalam kepribadian mereka untuk berinteraksi sebagai makhluk sosial. Keteladanan orangtua dan guru telah dijelaskan oleh Ki Hajar Dewantara dalam filosofinya, yaitu ing ngarso sung tuladho, yang artinya orang tua dan guru haruslah memberikan contoh yang baik kepada anak mereka (Noor, 2012).

Menjadi orangtua, motivasi dan dukungan menjadi indikator keberhasilan anak untuk lebih percaya diri dalam berperilaku. Guru sebagai tenaga pendidik yang profesional, bukan hanya mengajarkan ilmu pengetahuan, akan tetapi juga memberikan teladan yang baik kepada anak yang dimulai pada diri sendiri, sehingga dapat memberikan energi positif kepada anak untuk meniru perilaku yang baik. Guru seharusnya memiliki kemampuan untuk memberikan contoh kepada anaknya (Kusumaningrum, 2014). Oleh karena itu, peran orangtua dan guru menjadi sangat penting dalam mengembangkan 
karakter anak melalui keterlibatan dan kolaborasi antara orangtua dan guru. Dalam mengembangkan karakter anak, SD Muhammadiyah Sapen telah melakukan upaya dengan melaksanakan berbagai kegiatan yaitu: ekstrakurikuler (pustakawan kecil, pencak silat tapak suci, seni tari, sekolah sepakbola, petugas pecinta kebersihan, hizbul wathan, olahraga basket, belajar karawitan, broadcasting), ibadah shalat berjamaah, shalat sunnah duha' berjamaah dan kultum, tahfidz, CMIPA (Math and Privileged Class Smart IPA), pelatihan PKS (Patroli Keamanan Sekolah), pertemuan orang tua (diskusi perkembangan anak), dan pengajian safina. Dari berbagai program yang dilaksanakan adalah sebagai upaya dalam mengimplementasikan pendidikan karakter di lingkungan sekolah dan rumah. Dukungan dari orangtua menjadi salah satu aspek keberhasilan pelaksanaan pendidikan karakter. Oleh karena itu, guru dan orangtua sebagai bagian yang memiliki kontribusi paling penting dalam menanamkan nilai-nilai karakter dan sebagai panutan bagi anak.

Berdasarkan penjabaran di atas, peran orangtua dan guru sangat penting dalam mengembangkan nilainilai karakter anak dan memiliki dampak terhadap pencapaian prestasi akademik dan non akademik anak. Karena kolaborasi antara orangtua dan guru dapat memberikan dorongan dan kepedulian terhadap pendidikan mereka. Maka dari itu, tujuan dari penelitian ini adalah untuk menganalisis peran orangtua dan guru dalam mengembangkan karakter anak, faktor-faktor yang mempengaruhi pengembangan karakter anak, dan dampak dari peran orangtua dan guru terhadap pengembangan karakter anak.

\section{B. METODE PENELITIAN}

Penelitian ini menggunakan pendekatan kualitatif deskriptif yang bertujuan untuk mendeskripsikan permasalahan secara mendalam terhadap perilaku dan kejadian secara alami peran orangtua dan guru dalam mengembangkan karakter anak. Jenis deskriptif digunakan untuk merefleksikan data secara akurat menggunakan kalimat, mendeskripsikan kejadian dan faktafakta yang kompleks di lapangan. Subjek penelitian ditentukan menggunakan teknik purposive sampling berdasarkan kriteria dan pertimbangan tertentu untuk mendapatkan informasi lebih efektif. Adapun subjek penelitian terdiri dari: kepala sekolah, guru kelas, guru pendidikan Agama, ketua komite, dan orangtua.

Pengumpulan data dilakukan melalui wawancara, observasi dan dokumentasi. Untuk memperoleh keabsahan data menggunakan teknik triangulasi sumber yaitu mengecek dan membandingkan data yang diperoleh memiliki kesamaan dengan sumber data yang lain, artinya data yang diperoleh melalui teknik wawancara memperoleh data yang sama dengan teknik observasi dan dokumentasi. Data kemudian dianalisis dengan model interaktif yang mengikuti format dari Miles \& Huberman (1992) yang meliputi: reduksi data, penyajian data dan penarikan kesimpulan.

\section{HASIL DAN PEMBAHASAN}

Orang tua menjadi figur yang utama anak dalam menentukan sikap, terutama dalam memberikan teladan yang baik. Kehadiran orangtua bagi anak adalah sebagai sumber pengetahuan tentang pendidikan karakter, sebagai cerminan anak, orangtua sangat berperan dalam 
memberikan keteladanan. Selain itu telah dijelaskan peran utama guru dalam mengembangkan nilai karakter adalah keteladanan (Asmani, 2012). Peran keduanya sangat memberikan dampak yang positif dalam mengembangkan nilai-nilai karakter anak.

Orangtua dan guru memiliki komitmen terhadap aturan baik di lingkungan rumah dan sekolah, hal ini dilihat dari sikap, ucapan, dan tindakannya. Misalnya dengan memberikan contoh datang lebih awal ke sekolah, mengikuti setiap program sekolah, menghormati orang yang lebih tua, membantu pekerjaan rumah, dan selalu mendengarkan nasehat. Orangtua dan guru memotivasi anak untuk selalu mentaati aturan yang ada dan berusaha memfasilitasi yang dibutuhkan dalam mengembangkan karakter anak.

Sebagai orang yang diteladani, orangtua dan guru lebih banyak menjadi panutan bagi anak dalam berkepribadian. Contoh keteladanan itu adalah lebih kepada sikap jujur, toleransi, disiplin, bertanggung jawab, religius, gemar membaca, dan peduli terhadap orang lain dan lingkungan. Sikap dan perilaku orangtua dan guru dalam kehidupan sehari-hari sebagai sumber pengetahuan, yang secara langsung atau tidak akan ditiru dan digugu oleh anak sehingga menjadi bekal sampai dewasa. Keberadaan keduanya dipandang sebagai role model (teladan) yang akan digugu serta ditiru oleh anak (Suparlan, 2005).

\section{Peran Orang Tua sebagai Role Model}

Orang tua menginginkan yang terbaik untuk anaknya, maka sikap dan perilaku anak harus dibentuk dan dikembangkan sehingga mencerminkan sikap yang baik. Oleh sebab itu, sebagai orang yang ditiru orang tua sangat memperhatikan bagaimana harus bersikap dengan anak dan orang lain, karena memberikan contoh secara langsung akan diingat dengan baik oleh anak. Meskipun sikap orangtua kadang menerapkan pola asuh otoriter, akan tetapi membentuk karakter anak dengan baik. Karena perkembangan karakter seorang anak, sangat dipengaruhi oleh masa kecilnya.

Sebagai sumber ilmu pengetahuan di rumah, ada beberapa peran orangtua sebagai role model dalam mendidik karakter anak.

1. Membimbing anak untuk selalu memperhatikan waktu dan melaksanakan shalat berjama'ah dan membaca Al-Qur'an;

2. Mengajak anak untuk menjenguk tetangga yang sedang sakit;

3. Membentuk kebiasaan-kebiasaan baik di rumah, seperti membersihkan halaman rumah, merapikan kamar tidur, menyirami tanaman, dan pekerjaan rumah lainnya.

4. Memperkenalkan karakter yang baik kepada anak, seperti menghormati orang yang lebih dewasa, berkata jujur dan sopan, bertanggung jawab, serta sikap toleransi karena dengan demikian anak akan belajar sebagai makhluk sosial dalam lingkungan masyarakat.

Sebagai orang yang meletakkan pendidikan dasar karakter anak, maka orang tua harus memiliki kepribadian yang baik, karena anak bagaikan kertas putih yang bisa dituangkan apapun, baik itu positif maupun negatif. Oleh karena itu, tugas orang tua adalah memperkenalkan karakter yang baik kepada anak. Mulai dari pembiasaan-pembiasaan sederhana di rumah sampai pada bagaimana berperilaku dengan orang lain. Mengembangkan pendidikan karakter kepada anak, orang tua memberikan 
contoh dan menjelaskan kepada anak manfaat dari apa yang dilakukan atau dikerjakan. Sehingga pendidikan karakter bukan hanya sekedar pengetahuan, akan tetapi menjadi sebuah kebiasaan (habit) yang dilakukan secara berulang-ulang sampai dewasa.

\section{Peran Guru sebagai Role Model}

Konsep peran guru sebagai role model adalah satu contoh lebih baik dibandingkan dengan seribu nasihat. Guru sebagai role model adalah guru yang dapat memberikan contoh perilaku yang baik kepada anak. Misalnya, guru mengatakan, "Anak harus jujur dan disiplin," maka guru terlebih dahulu harus mencerminkan sikap jujur dan disiplin, karena dengan contoh, dapat memberikan kesadaran kepada anak untuk meniru perilaku tersebut. Oleh karena itu, guru memiliki peran yang sangat menentukan perilaku atau karakter anak di Sekolah. Adapun beberapa contoh yang diberikan guru dalam lingkungan sekolah berdasarkan hasil observasi, yaitu:

1. Datang lebih awal ke sekolah sebelum upacara dan jam pelajaran berlangsung;

2. Merapikan meja dan koleksi bukubuku di dalam ruangan kelas;

3. Siap sedia mendampingi anak dalam mengikuti program pendidikan karakter sekolah, seperti: petugas pecinta kebersihan, ibadah shalat berjamaah, shalat sunnah duha' berjamaah dan kultum, tahfidz, CMIPA (Math and Privileged Class Smart IPA), dan pelatihan PKS (Patroli Keamanan Sekolah), dan pengajian safina;

4. Melaksanakan tugas sebagai pengajar secara profesional dan melakukan komunikasi yang baik dengan orangtua anak;

5. Perhatian dan peduli kepada anak, mengajak anak untuk menjenguk temannya ketika dalam keadaan sakit.

Keteladanan yang ditunjukkan oleh guru lebih banyak melakukan perbuatan daripada hanya sekedar berbicara. Guru lebih mengutamakan perbuatan dalam menanamkan nilai pendidikan karakter (learn to do), sehingga guru juga ikut terlibat di dalamnya. Sebagai orang yang ditiru, guru memiliki sikap yang baik, sopan dalam berbicara, dan memiliki sikap toleransi. Karena tugas guru bukan hanya mentransfer pengetahuan, akan tetapi mengubah dan membentuk karakter anak, sehingga memiliki budi pekerti yang luhur serta berkarakter. Guru juga harus membangun komunikasi yang baik dengan anak, sehingga anak merasa cinta kepada gurunya, sehingga menciptakan kehangatan dan keharmonisan antara guru dengan anak (Zuriah, 2015).

Dalam mengembangkan karakter anak, dapat dilakukan dengan memberikan teladan dan motivasi, memberikan pengarahan dan bimbingan, serta memperlakukan anak sebagai orang yang dapat berubah menjadi lebih baik, sehingga anak merasa dihargai dan mentaati aturan di sekolah. Maka dari itu, anak sangat mengharapkan guru untuk mencontohkan perilaku yang baik seperti: peduli terhadap anak, ramah, sopan, jujur, disiplin, tanggungjawab, pintar dan memiliki wawasan yang luas berkaitan dengan informasi baru sehingga anak akan terdorong untuk belajar lebih semangat dan tekun lagi.

Oleh sebab itu, Suharsaputra (2013) menjelaskan bahwa karakter guru yang baik berdasarkan pandangan anak adalah: 1) memberikan inspirasi, sehingga menjadi sumber inspirasi; 2) simpati dan suka menolong, serta peduli sehingga dapat membangun hubungan personal yang baik; 3) memotivasi untuk bekerja keras; 4) berkomunikasi 
yang baik; 5) sangat humoris; 6) memiliki pengetahuan lebih; 7) mendengarkan pendapat; 8) Interaktif dalam pembelajaran; 9) disiplin dan percaya diri; 10) mampu mengendalikan emosi; 11) pemecah masalah; 12) bersikap adil; 13) punya dedikasi sebagai guru; dan 14) pemimpin dan teman yang baik bagi anak di sekolah.

Orangtua dan guru memiliki peran yang sangat vital dalam mengembangkan nilai-nilai pendidikan karakter kepada anak. Kepala sekolah dan komite SD Muhammadiyah Sapen mengungkapkan bahwa sekolah harus melakukan hubungan bilateral dengan berbagai kalangan dalam mendorong pendidikan karakter anak. Karena hal ini bukan hanya tanggung jawab sekolah, akan tetapi merupakan tanggungjawab bersama antara sekolah, orangtua, dan masyarakat. Maka dari itu, perlu adanya kerjasama yang baik untuk melakukan komunikasi dan koordinasi dalam membentuk karakter anak, sehingga memiliki budi pekerti yang luhur berdasarkan budaya bangsa.

\section{Faktor-Faktor yang Mempengaruhi Pengembangan Karakter Anak}

\author{
Adapun faktor-faktor yang \\ mempengaruhi pengembangan \\ karakter anak yaitu faktor pendukung \\ dan penghambat.
}

1. Faktor pendukung

Faktor pendukung dalam pengembangan nilai karakter anak dipengaruhi oleh: a) Standar isi kurikulum yang digunakan oleh SD Muhammadiyah Sapen adalah kurikulum 2013. Salah satu sekolah dasar yang terakriditasi A dengan mengimplementasikan pendidikan karakter dalam pembelajaran, dengan pendekatan saintifik berbasis karakter. Yang dimana nilai-nilai karakter dipadukan dalam proses pembelajaran, manajemen sekolah, dan ekstrakurikuler; b) Kepemimpinan kepala sekolah. Gaya kepemimpinan kepala sekolah yang dapat merangkul semua guru, ikut terlibat dalam program sekolah, dinamis dan terbuka. Penilaian dari orang tua anak bahwa karakter kepemimpinan kepala sekolah dapat menjadi salah satu indikator keberhasilan program sekolah dalam penguatan pendidikan karakter. Pemimpin yang baik, transparan, menjalin hubungan yang harmonis dengan stakeholder sekolah, dan memiliki rasa kepedulian tinggi terhadap pendidikan dan pengembangan karakter anak di sekolah; c) Komitmen seluruh warga sekolah yang mendukung secara penuh program sekolah dalam pengembangan karakter anak dan mewujudkan visi dan misi sekolah, sehingga terjalin kerjasama yang baik antara kepala sekolah, guru, komite, orang tua, dan seluruh warga sekolah untuk mentaati dan disiplin terhadap kebijakan dan aturan sekolah; d) Melibatkan peran orangtua dalam program sekolah. Orangtua merupakan orang yang dekat dengan anak, yang dapat dijadikan sebagai partner untuk meningkatkan kepedulian dan tanggung jawab terhadap pengembangan karakter anak. Untuk itu melibatkan orangtua dalam program sekolah dapat mendorong pendidikan karakter anak (Ditjen PAUD dan Dikmas, 2017).

2. Faktor penghambat

Ada beberapa faktor yang menjadi penghambat pengembangan nilai karakter anak, yaitu: a) Kurangnya kepedulian dari beberapa orangtua dan guru. Sikap ini muncul karena 
berbagai alasan. Bagi orang tua, menyerahkan pendidikan sepenuhnya kepada sekolah, karena mereka merasa sibuk dengan pekerjaannya dan tugas guru adalah harus menjadikan anaknya lebih pintar dan berperilaku baik. Sedangkan bagi guru, banyak tanggung jawab yang harus dikerjakan oleh guru selain mengajar, mulai dari mempersiapkan perangkat pembelajaran, penilaian dan pekerjaan lain selain menjadi guru, sehingga tidak fokus untuk membantu program-program sekolah dalam pengembangan nilai karakter anak; b) Minimnya pengetahuan orangtua tentang pendidikan karakter. Kurangnya sosialisasi dari pihak sekolah tentang pendidikan karakter kepada orang tua menjadi salah satu penyebab pengetahuan orangtua menjadi minim, dan mereka sulit untuk membimbing anak di rumah. Sehingga terjadi ketidak keselarasan bimbingan anak antara di sekolah dengan di rumah. Anak lebih banyak menghabiskan waktunya untuk bermain daripada mengulangi pelajaran, shalat berjama'ah, membaca Al-Qur'an, dan kegiatan lainnya untuk penguatan pendidikan karakter. Kurangnya pengetahuan orangtua tentang pendidikan karakter menjadikan perilaku anak tidak terkontrol dan tidak mencerminkan perilaku yang baik.

Sebagai orang yang digugu dan ditiru oleh anak, orangtua dan guru harus menunjukkan karakter yang baik melalui sikap, tutur kata, dan tingkah lakunya. Karena keduanya memiliki peran sebagai sumber norma, nilai ilmu pengetahuan, penerus sistem nilai, penerjemah sistem nilai, terciptanya proses edukatif di lingkungan rumah maupun di sekolah.
Oleh karena itu, peran orangtua dan guru sangat penting dalam membangun komitmen bersama untuk mengembangkan nilai-nilai karakter terhadap anak. Orangtua dan guru juga dapat berperan dalam memberikan kasih sayang, mengayomi, dan membimbing, karena mendidik bukan hanya dapat dilakukan ketika berada di dalam ruang kelas, akan tetapi bisa dapat dilakukan di luar dengan cara membimbing anak.

\section{Dampak Peran Orang Tua dan Guru dalam Pengembangan Karakter Anak}

Secara garis besar, peneliti merumuskan dua aspek yang menjadi dampak peran orangtua dan guru dalam pengembangan karakter anak, diantaranya adalah:

1. Nilai-nilai karakter berpengaruh terhadap prestasi belajar anak.

Program pendidikan karakter telah mendorong prestasi belajar anak, hal ini dapat dilihat dari prestasi yang didapatkan anak dalam ajang kompetisi nasional maupun internasional (olimpiade IPA, Matematika, dan olahraga). Selain itu, hasil Ujian Nasional SD 2019, SD Muhammadiyah Sapen mencatat rata-rata tertinggi seDaerah Istimewa Yogyakarta. Prestasi ini merupakan kerja keras kita bersama, baik dari pihak sekolah, orangtua dan masyarakat yang terus memberikan dukungan, hal ini sering disampaikan oleh kepala sekolah ketika siswa berhasil meraih juara. Sehingga kolaborasi antara sekolah dan orang tua dapat membantu program pendidikan karakter. Hal ini didukung oleh penelitian Beninga, at al. (2003) dengan meneliti 120 sekolah di California menunjukkan bahwa pendidikan karakter yang dikembangkan oleh sekolah 
memiliki pengaruh terhadap prestasi belajar siswa. Dalam mengembangkan pendidikan karakter 120 sekolah dasar tersebut menggunakan 6 standar, yaitu: 1). sekolah mensosialisasikan nilainilai karakter sebagai karakter yang akan dikembangkan; 2). orangtua dan masyarakat berpartisipasi aktif dalam pendidikan karakter; 3). pembentukan nilai-nilai karakter dilakukan secara bertahap, dengan diawali pada kehidupan sekolah; 4). staf sekolah dan guru membagi tugas dan tanggung jawab dalam pelaksanaan; 5). Sekolah membantu mengembangkan ke berbagai komunitas; dan 6). sekolah memberikan kesempatan kepada siswa untuk berperilaku moral.

Maka dari itu, semakin kuat pendidikan karakter anak, maka akan meningkatkan prestasi. Karena pendidikan karakter lebih memiliki peranan dalam prestasi anak, jika dibandingkan dengan kecerdasan emosi (Irjanti \& Setiawati, 2018). Dengan karakter tersebut mendorong anak untuk memiliki motivasi yang kuat sehingga berpengaruh pada prestasi belajar. Selain itu, anak memiliki self efficacy atau keyakinan untuk menyelesaikan tugas dengan baik.

2. Terjadinya perubahan perilaku yang muncul pada anak.

Penanaman

nilai-nilai karakter melalui pendidikan yang terjadi di lingkungan rumah dan sekolah, pembiasaan yang baik, serta teladan berkarakter sangat memberikan pengaruh positif terhadap pengembangan karakter anak. Peran orangtua dan guru sebagai role model sangat dibutuhkan oleh anak, sehingga anak dapat meniru karakter baik yang dilihat dari orangtua dan guru sebagai figur utama. Keberadaan mereka sebagai teladan dan membimbing anak untuk dapat menanamkan nilai karakter melalui pembiasaan, sehingga menjadi perilaku yang dilakukan secara berulang-ulang menjadi terbiasa (habit).

Sebagai figur yang diutamakan, orang tua dan guru harus memiliki nilai-nilai karakter yang luhur, seperti religius, toleransi, jujur, disiplin, kreatif, mandiri, kerja keras, demokratis, rasa ingin tahu, semangat kebangsaan, cinta tanah air, menghargai prestasi, gemar membaca, bersahabat atau komunikatif, cinta damai, peduli sosial dan lingkungan, dan tanggung jawab (Kemendiknas, 2010).

Salah satu metode yang digunakan oleh orangtua dan guru dalam mengembangkan pendidikan karakter adalah sebagai teladan dan pembimbing untuk membangun anak memiliki moral, dan kebiasaan yang dikembangkan dalam lingkungan rumah, pembelajaran di kelas dan sekolah untuk membangun karakter anak yang berguna bagi kehidupan masa depannya.

Pengelolaan pendidikan karakter dapat dilakukan dengan kolaborasi antara internal sekolah dan eksternal sekolah. Dalam internal sekolah ada empat strategi yang dilakukan, yaitu kegiatan belajar mengajar (KBM), budaya sekolah (school culture), kegiatan ekstrakurikuler, dan pembiasaan (habituation). Sedangkan eksternal sekolah adalah dukungan dari lingkungan keluarga dan masyarakat (Maunah, 2015). Pembiasaan yang dikembangkan antara di rumah dan sekolah bersinergi dengan baik, sehingga sekolah perlu mengkomunikasikan kebiasaan anak yang dikembangkan di sekolah, dengan harapan orangtua dapat melakukan yang sama, seperti shalat berjama'ah, membaca Al-Qur'an, disiplin, toleransi dan peduli. 
Perubahan perilaku anak ini muncul karena adanya transparansi dari kepala sekolah dan guru untuk mengkomunikasikan kepada orang tua terkait dengan program pendidikan karakter yang dikembangkan oleh sekolah. Namun, pembiasaan itu dimulai dari kepala sekolah, staf dan guru, serta orang tua sehingga dapat ditiru oleh anak.

Peran orang tua dan guru sebagai figur yang memberikan teladan yang baik kepada anak menjadi sebuah keharusan, mengingat pendidikan bukan hanya menyampaikan ilmu pengetahuan, akan tetapi juga mendidik dan membimbing karakter anak menjadi lebih baik. Sehingga sekolah perlu menyampaikan perkembangan dan prestasi yang diperoleh oleh anak. Sehingga orangtua dan guru dapat bekerjasama untuk mendidik anak ketika anak mengalami masalah. Selain itu, memberikan motivasi dan memfasilitasi anak sehingga memiliki kesadaran untuk meniru kebiasaankebiasaan baik yang dilihat maupun dilakukan. Maka dari itu, orangtua dan guru bukan hanya menyuruh anak untuk berperilaku baik, tetapi memberikan contoh yang baik, karena satu contoh lebih baik daripada seribu nasihat.

Melihat kenyataan ini, maka orang tua dan guru harus berusaha introspeksi diri agar memiliki karakter terpuji (baik), sehingga dapat dijadikan sebagai figur atau role model bagi anak. Oleh karena itu, dibutuhkan kesadaran dan tanggung jawab dari semua orang tua dan guru yang dapat digugu dalam bersikap, berbuat, dan bertutur kata. Maka dapat disimpulkan bahwa pengembangan karakter anak berada ditangan orang tua dan guru sebagai pendidik dan memberikan teladan yang berkarakter, sebab keduanya dijadikan sebagai "bahan ajar" dalam bersikap dan berkepribadian. Selain itu, orang tua dan guru sangat diharapkan memberikan energi positif kepada anak sehingga menjadi manusia yang cerdas dan berkarakter.

\section{SIMPULAN}

Peran orang tua dan guru sebagai teladan dalam pengembangan karakter anak adalah sebagai teladan berkarakter yang ditunjukkan melalui bersikap, berbuat, dan bertutur kata, seperti sikap jujur, toleransi, disiplin, bertanggung jawab, religius, dan peduli terhadap orang lain serta lingkungan. Peran orang tua dan guru terus diupayakan melalui program pendidikan karakter di sekolah, seperti shalat berjama'ah, kultum, membaca Al-Qur'an, pertemuan orangtua, dan kegiatan ekstrakurikuler. Faktor-faktor yang mempengaruhi pengembangan karakter anak, yaitu: 1) standar isi kurikulum yang digunakan oleh SD Muhammadiyah Sapen adalah kurikulum 2013; 2) gaya kepemimpinan kepala sekolah yang dapat merangkul semua guru, ikut terlibat dalam program sekolah, dinamis dan terbuka; 3) komitmen seluruh warga sekolah; 4) melibatkan peran orang tua dalam program sekolah. Sedangkan faktor penghambatnya adalah 1) kurangnya kepedulian dari beberapa orangtua dan guru, karena banyaknya tugas dan tanggungjawab; 2) minimnya pengetahuan orang tua tentang pendidikan karakter. Namun dampak dari peran dari orang tua dan guru dalam pengembangan karakter anak adalah 1) pendidikan karakter telah mendorong prestasi belajar anak; 2) munculnya perubahan perilaku pada anak. Oleh karena itu, kesadaran dan tanggung jawab orangtua dan guru yang dapat diteladani dalam bersikap, berbuat, dan bertutur kata. Selain itu, keduanya sebagai "bahan ajar" 
pendidikan karakter dan sangat diharapkan memberikan energi positif kepada anak.

\section{DAFTAR RUJUKAN}

Agustina, P. (2018). Karakteristik Perilaku Kepemimpinan Kepala Sekolah dan Budaya Sekolah di Sekolah Dasar. Jurnal Pendididkan Karakter, Tahun VIII(Oktober 2018), 206-219.

Asmani, Jamal. (2012). Buku Panduan Internalisasi Pendidikan Karakter di Sekolah. Yogyakarta: DIVA Press.

Cecillia, Nova, Jumaini, \& Ganis, Indriati. (2014). Hubungan Penerapan Pendidikan Karakter terhadap Perilaku Sosial Siswa. JOM PSIK. Vol. 1, (2), 1-6

Ditjen PAUD dan Dikmas. (2017). Petunjuk Teknis Pelibatan Keluarga pada Penyelenggaraan Sekolah Dasar. Jakarta: Kementerian Pendidikan dan Kebudayaan.

Hardiyana, Siti. (2014). Pengaruh Guru PKn terhadap Pembentukan Karakter Siswa. Jurnal Ilmiah PPKn IKIP Veteran Semarang. Vol. 2 (1), 54-64.

Irjanti, R., \& Setiawati, A. (2018). Pengaruh Nilai-Nilai Karakter Terhadap Prestasi Belajar di SDIT Salman Al Farisi. Jurnal Pendidikan Karakter, Tahun VIII, 40-50.

Iv, D. A. N., Kec, R., \& Banyumas, K. (2017). Program Parenting Berkelanjutan TK Aisyiyah I, II , III, I(September), 125-135.

Kusumaningrum, D. Yunita. (2014). Peran Guru dalam Membentuk Karakter Kepemimpinan pada Peserta Didik di SMA Al Hikmah Surabaya. Jurnal Inspirasi Manajemen Pendidikan, Vol. 4. 190-200.

Kemendiknas. (2010). Pengembangan Pendidikan Budaya dan Karakter
Bangsa Pedoman Sekolah.

Jakarta: Kemendiknas.

Lies, J., Bronk, K., C \& Mariano, J.M. (2008). The Community Contribution to Moral Development and character. Dalam Nucci, L.P \& Narvaes, D. (Eds.). Handbook of Moral and Character Education. New York: Routledge. (520-536).

Maunah, B. (2015). Implementasi Pendidikan Karakter dalam Pembentukan Kepribadian Holistik Siswa. Pendidikan Karakter, V(1), 90-101. https://doi.org/http://dx.doi.org/1 $0.21831 /$ jpk.v0i1.8615

Miles, M.B \& Huberman, A.M. (1992). Analisis Data Kualitatif. (Terjemahan oleh Tjetjep Rohendi Rohidi). Jakarta: UI Press.

Noor. R. M. (2012). The Hidden Curriculum, Membangun Karakter Melalui Kegiatan Ekstrakurikuler: Yogyakarta: Insan Madani.

Palunga, R., \& Marzuki. (2017). Peran Guru dalam Pengembangan Karakter Peserta Didik di Sekolah Menengah Pertama Negeri 2 Depok Sleman. Pendidikan Karakter, Tahun VII, 109-123.

Uli, I. (2018). Implementasi nilai pendidikan karakter dalam sastra lisan di IKIP PGRI Pontianak. Jurnal Pendidikan Dasar dan Pembelajaran, 8(2), 140-149. https://doi.org/10.25273/pe.v8i2. 2911

Steinberg, L. (1996). Beyond The Classroom: Why School Reform has Failed and what Parent Need to Do. New York: Simon \& Schuster.

Sugihandari.(2015, 5 Mei) Pentingnya Partisipasi Keluarga dalam Pendidikan Anak, Kompas online. 
Suharsaputra, Uhar. (2013). Menjadi Guru Berkarakter. Bandung: PT Refika Aditama.

Suparlan. (2005). Menjadi Guru Efektif. Yogyakarta: Hikayat.

Zaini, A.H.F. (2013). Pilar-pilar Pendidikan Karakter Islam.
Bandung: Gunung Djati Press. Zuriah, Nurul. (2015). Pendidikan Moral \& Budi Pekerti dalam Perspektif Perubahan. Jakarta: Bumi Aksara. 